\title{
Comparative Quality Loss in Wild and Cultured Rainbow Trout (Oncorhynchus mykiss) during Chilling Storage
}

\author{
Fatih Ozogul, Emre Yavuzer, Yesim Ozogul and Esmeray Kuley* \\ Department of Seafood Processing Technology, Faculty of Fisheries, University of Cukurova, 01330, Balcall, Adana/Turkey
}

Received August 14, 2012; Accepted February 7, 2013

The aim of this study was to determine and compare differences in sensory, chemical and microbiological post-mortem changes between wild and farmed rainbow trout (Oncorhynchus mykiss). Lipid content was higher $(5.77 \%)$ in wild fish than cultured fish $(\mathbf{3 . 0 2} \%)$. Wild fish were very rich in $\mathbf{n}-3$ fatty acids. Although wild fish were preferred to cultured fish due to the taste and flavour, shelf life of both wild and cultured rainbow trout was 14 days with demerit scores of 16 and 14, respectively. Chemical analyses showed that lipid oxidation and hydrolysis developed at a higher rate in wild rainbow trout. Histamine was not detected in any samples throughout the storage period apart from wild rainbow trout at 7 days of storage. Initial total viable counts (TVC) of fish was $3.59 \mathrm{log}$ CFU/g for cultured rainbow trout and $3.36 \mathrm{log} \mathrm{CFU} / \mathrm{g}$ for wild rainbow trout, which showed high quality of fish. Coliform and $E$. coli were not detected for both groups. When fish were unacceptable at the days of 14 , TVC content was $6.16 \log \mathrm{CFU} / \mathrm{g}$ for wild rainbow trout and $6.35 \log \mathrm{CFU} / \mathrm{g}$ for cultured rainbow trout.

Keywords: wild fish, cultured fish, freshness quality, shelf-life, biogenic amines

\section{Introduction}

The demand for animal protein for human consumption is currently on the rise and aquaculture has been an important source of fish available for human consumption (Zhou et al., 2012). Due to high-cost of wild-captured fish, the fish culture industry has developed greatly in Europe, particularly in the Mediterranean region (Nasopoulou and Zabetakis, 2012). Rainbow trout (O. mykiss) belonging to the Salmonidae family is the most common cultured fish with high commercial value and much appreciated in European countries. As one of the main species farmed in Mediterranean countries, the demand for fresh rainbow trout has increased and the investigation of quality changes during storage continues to be main interest to industries, retailers and consumers.

Previous studies related to the comparison of wild and cultured fish indicated that significant differences in proximate, chemical and organoleptic characteristics of wild and farmed samples of the same species. Fallah et al. (2011) determined differences between farmed and wild rainbow trout in terms of proximate and fatty acid composition, physico-

*To whom correspondence should be addressed.

E-mail: ebogal@cu.edu.tr chemical parameters and mineral content. Grigorakis et al. (2002) investigated major quality parameters (muscle composition, fat deposition, muscle fatty acid composition and external appearance) in wild and cultured gilthead sea bream. Grigorakis et al. (2003) also determined whether there are organoleptic differences among wild and cultured gilthead sea bream (Sparus aurata) and to find their possible chemical basis. The proximate, fatty acid and trace mineral compositions in the flesh of cultured and wild sea bass (Dicentrarchus labrax) were evaluated (Alasalvar et al., 2002). Limited information exists on the sensory, chemical and microbiological differences of wild and cultured rainbow trout. Therefore, the aim of the current study was to determine and compare differences in sensory (raw and cooked), chemical (proximate composition, fatty acid profile, total volatile basic nitrogen (TVB-N), peroxide value (PV), thiobarbituric acid (TBA), free fatty acids (FFA), biogenic amines) and microbiological (TVC, coliform and Escherichia coli) post-mortem changes between wild and cultured rainbow trout (O. mykiss).

\section{Materials and Methods}

Fish samples Fresh aquacultured rainbow trout ( $O$. mykiss) was obtained from an aquaculture farm located on 
river Ecemis in the southern (Camardi, Nigde, Turkey) in October 2010. Wild rainbow trout were obtained from the same river in October 2010. Aquacultured fish were fed with pellet feed (Agromey, Izmir, Turkey) for 13 month with an average water temperature of $6-7^{\circ} \mathrm{C}$. Aquacultured and wild rainbow trout are caught by dip net. The average weight and length of the both samples were $250 \pm 7.6 \mathrm{~g}$ and $20 \pm 2$ $\mathrm{cm}$, respectively. Fish were killed by hitting on head and delivered to the laboratory in ice within $6 \mathrm{~h}$ of harvesting. They were left ungutted and immediately packed in polystyrene boxes containing ice. Data were obtained using three fish (as muscle) for each of the assay at 0, 3, 7, 10, 14, 17 and 19 days of storage.

Sensory evaluation For sensory analysis, triplicate samples were taken at regular intervals. Sensory analysis was assessed using the Tasmanian Food Research Unit scheme (Branch and Vail, 1985) with modifications. This sensory assessment approach evaluates freshness by giving demerit points according to certain aspects of general appearances (skin, slime, eyes, belly, odour etc.). Each assessment was carried out by a minimum of 6 trained panellist. Panellists were asked to state whether or not the fish were acceptable. This was used to determine the shelf life of trout.

The measurement of freshness of cooked fish (odour. flavour and texture) was assessed according to Torry Scheme (Howgate, 1982). A scale from 10 to 3 was used, 10 denoting absolutely fresh fish and 3 indicating a spoiled, putrid fish. To prepare the cooked fish sample, fish were cooked in a microwave for 2 minutes at medium temperature $(600 \mathrm{~W})$. The cooked samples were served hot to panellists.

Chemical analysis The samples were analysed in triplicate for proximate composition: lipid content by the Bligh and Dyer (1959) method, moisture content by the AOAC (1990) method, total crude protein by the Kjeldahl method (AOAC, 1998a), ash content by the AOAC (1998b) method and fatty acid content by Ichihara et al. (1996). TVBN was determined using the method of Antonacopoulus (1973) and expressed as mg TVB-N/100 $\mathrm{g}$ fish muscle. TBA index was determined according to the method of Tarladgis et al. (1960). TBA content was expressed as $\mathrm{mg}$ of malondialdehyde (MDA)/kg fish muscle. PV expressed in miliequivalents of peroxide oxygen $/ \mathrm{kg}$ of fat and was determined according to AOCS (1994). FFA analysis, expressed as \% of oleic acid was determined according to the AOCS method (1994).

Biogenic amines were analysed using an HPLC method (Ozogul et al., 2002). Benzoyl chloride as a derivatization reagent was used and the derivatization procedure was based on that of Redmond and Tseng (1979).

Apparatus High-performance liquid chromatography (HPLC) used Shimadzu LC-10VP (Shimadzu, Kyoto, Japan) apparatus equipped with a UV/VIS detector (Spectra-Physics SP 8450, Analytical Inc.. UK) and a low gradient pump (Shimadzu LC-10ATVP) with four-channel mixer (Shimadzu FVC-10ALVP). For biogenic amine analysis, the column was reverse-phase, C18, nucleosil, $250 \times 4.6 \mathrm{~mm}$, particle diameter $5 \mu \mathrm{m}$ (Mecherey-Nagel, Duren, Germany).

Microbiological analysis Samples from each of three different fish (triplicate) were taken to estimate TVC. Ten grams of fish muscle were mixed with $90 \mathrm{~mL}$ of Ringer solution and then homogenised for 3 min. Further decimal dilutions were made up to $10^{-8}$ and then $0.1 \mathrm{~mL}$ of each dilution was pipetted onto the surface of plate count agar plates in triplicate. This method was carried out under hygienic conditions, particularly during sampling procedure. They were then incubated for 2 days at $30^{\circ} \mathrm{C}$. For total coliform bacteria, Violet Red Bile Agar (VRBA, Oxoid, CM0107) was used. Escherichia coli counts were determined using Mac Conkey Agar with MUG (Merck 1.01406) as the medium. Plates were incubated at $30^{\circ} \mathrm{C}$ for $24 \mathrm{~h}$.

Statistical Analyses Analyses were run in triplicate and results were reported as mean values \pm standard deviation (S.D.). Data were subjected to analysis of variance (one-way ANOVA).

\section{Results and Discussion}

Proximate composition Significant differences were observed $(p<0.05)$ in the protein, lipid and moisture contents of fish except ash content. Wild rainbow trout contained $21.43 \pm 0.25 \%$ protein whereas the protein content of cultured rainbow trout was $18.170 .45 \%$. Lipid content was higher $(5.77 \pm 0.61 \%)$ in wild fish than cultured fish $(3.02 \pm 0.22 \%)$. However, Fallah et al. (2011) reported that fat content of farmed rainbow trout fillets was higher, while moisture content was lower than wild rainbow trout. Grigorakis et al. (2002) also found that lipid content of cultured sea bream was much higher than that of wild fish. Tokur et al. (2006) reported higher protein level (22.96\%) and lower lipid content (2.71\%) for cultured rainbow trout compared to the current study. The differences in lipid content of cultured and wild fish were attributed to the constituents of the diet of the fish (Alasalvar et al., 2002). Cultured rainbow trout had significantly higher moisture content $(77.33 \pm 1.27 \%)$ compared to wild fish $(71.46 \pm 0.21)$, whilst they had similar ash content $(1.48 \pm 0.03$ vs $1.37 \pm 0.01 \%)$. Size or age, reproductive status, geographic location, and season all influence fat content and composition of fish muscle (Ackman, 1989).

Fatty acids profile Fatty acids compositions of wild and cultured rainbow trout are given in Tables 1 and 2. The highest proportions of fatty acids in fish were myristic acid (C14:0), palmitic acid (C16:0), palmitoleic acid 
Table 1. SFA and MUFA content of wild and cultured rainbow trout (\%).

\begin{tabular}{|c|c|c|c|c|c|c|c|c|}
\hline \multicolumn{9}{|c|}{ Storage time (days) } \\
\hline Fatty acids & Groups & 0 & 3 & 7 & 10 & 14 & 17 & 19 \\
\hline \multirow{2}{*}{ 14:0 } & Wild & $3.29 \pm 1.25^{\mathrm{a}}$ & $3.09 \pm 0.20^{\mathrm{a}}$ & $2.87 \pm 0.17^{\mathrm{a}}$ & $1.72 \pm 0.05^{\mathrm{a}}$ & $1.44 \pm 0.19^{\mathrm{a}}$ & $1.51 \pm 0.08^{\mathrm{a}}$ & $1.52 \pm 0.01^{\mathrm{a}}$ \\
\hline & Cultured & $2.99 \pm 0.07^{\mathrm{a}}$ & $2.78 \pm 0.12^{\mathrm{a}}$ & $2.89 \pm 0.07^{\mathrm{a}}$ & $2.84 \pm 0.06^{\mathrm{b}}$ & $2.92 \pm 0.01^{\mathrm{b}}$ & $2.79 \pm 0.18^{b}$ & $2.52 \pm 0.07^{\mathrm{b}}$ \\
\hline \multirow{2}{*}{ 16:0 } & Wild & $13.01 \pm 2.65^{\mathrm{a}}$ & $13.91 \pm 1.17^{\mathrm{a}}$ & $14.63 \pm 0.12^{\mathrm{a}}$ & $13.81 \pm 0.26^{\mathrm{a}}$ & $14.91 \pm 1.47^{\mathrm{a}}$ & $14.04 \pm 2.14^{\mathrm{a}}$ & $13.78 \pm 0.01^{\mathrm{a}}$ \\
\hline & Cultured & $11.54 \pm 0.21^{\mathrm{a}}$ & $12.05 \pm 0.37^{\mathrm{a}}$ & $12.03 \pm 0.41^{\mathrm{a}}$ & $12.88 \pm 0.31^{\mathrm{a}}$ & $11.62 \pm 0.50^{\mathrm{a}}$ & $12.39 \pm 0.41^{\mathrm{a}}$ & $13.44 \pm 0.06^{\mathrm{a}}$ \\
\hline \multirow{2}{*}{$17: 0$} & Wild & $0.31 \pm 0.30^{\mathrm{a}}$ & $0.19 \pm 0.03^{\mathrm{a}}$ & $0.15 \pm 0.04^{\mathrm{a}}$ & $0.09 \pm 0.02^{\mathrm{a}}$ & $0.19 \pm 0.08^{\mathrm{a}}$ & $0.16 \pm 0.02^{\mathrm{a}}$ & $0.16 \pm 0.01^{\mathrm{a}}$ \\
\hline & Cultured & $0.15 \pm 0.00^{\mathrm{b}}$ & $0.17 \pm 0.00^{\mathrm{a}}$ & $0.17 \pm 0.07^{\mathrm{a}}$ & $0.13 \pm 0.01^{\mathrm{a}}$ & $0.14 \pm 0.07^{\mathrm{a}}$ & $0.16 \pm 0.02^{\mathrm{a}}$ & $0.11 \pm 0.01^{\mathrm{a}}$ \\
\hline \multirow{2}{*}{ 18:0 } & Wild & - & $2.69 \pm 0.76^{\mathrm{a}}$ & $4.04 \pm 0.21^{\mathrm{a}}$ & $3.96 \pm 0.19^{\mathrm{a}}$ & $3.67 \pm 0.03^{\mathrm{a}}$ & $2.85 \pm 0.88^{\mathrm{a}}$ & $4.33 \pm 0.00^{\mathrm{a}}$ \\
\hline & Cultured & $2.75 \pm 0.16^{\mathrm{a}}$ & $3.01 \pm 0.33^{\mathrm{a}}$ & $2.85 \pm 0.08^{\mathrm{b}}$ & $3.12 \pm 0.05^{\mathrm{a}}$ & $1.44 \pm 0.04^{\mathrm{b}}$ & $3.05 \pm 0.36^{\mathrm{a}}$ & $3.40 \pm 0.24^{\mathrm{b}}$ \\
\hline \multirow{2}{*}{ 20:0 } & Wild & - & $0.21 \pm 0.04^{\mathrm{a}}$ & $0.13 \pm 0.02^{\mathrm{a}}$ & $0.11 \pm 0.01^{\mathrm{a}}$ & $0.16 \pm 0.03^{\mathrm{a}}$ & $0.25 \pm 0.02^{\mathrm{a}}$ & $0.08 \pm 0.00^{\mathrm{a}}$ \\
\hline & Cultured & $0.17 \pm 0.00^{\mathrm{a}}$ & $0.16 \pm 0.01^{\mathrm{a}}$ & $0.18 \pm 0.00^{\mathrm{a}}$ & $0.17 \pm 0.04^{\mathrm{a}}$ & $0.15 \pm 0.01^{\mathrm{a}}$ & $0.18 \pm 0.04^{\mathrm{a}}$ & $0.12 \pm 0.00^{\mathrm{a}}$ \\
\hline \multirow{2}{*}{$23: 0$} & Wild & $1.54 \pm 0.00^{\mathrm{a}}$ & $0.20 \pm 0.00^{\mathrm{a}}$ & $0.19 \pm 0.00^{\mathrm{a}}$ & $0.12 \pm 0.00^{\mathrm{a}}$ & $0.15 \pm 0.02^{\mathrm{a}}$ & $0.13 \pm 0.01^{\mathrm{a}}$ & $0.16 \pm 0.00^{\mathrm{a}}$ \\
\hline & Cultured & $0.11 \pm 0.01^{\mathrm{b}}$ & $0.05 \pm 0.00^{\mathrm{b}}$ & $0.10 \pm 0.08^{\mathrm{a}}$ & $0.06 \pm 0.00^{\mathrm{b}}$ & $0.04 \pm 0.00^{\mathrm{b}}$ & $0.09 \pm 0.01^{\mathrm{a}}$ & $0.17 \pm 0.00^{\mathrm{a}}$ \\
\hline \multirow{2}{*}{ Other fatty acids } & Wild & $0.52 \pm 0.09^{\mathrm{a}}$ & $1.32 \pm 0.10$ & - & $1.03 \pm 0.03$ & - & - & - \\
\hline & Cultured & $2.12 \pm 0.00^{\mathrm{b}}$ & - & - & - & - & - & - \\
\hline \multirow{2}{*}{$\sum$ SFA } & Wild & 19.00 & 21.63 & 22.02 & 20.94 & 20.54 & 18.95 & 20.03 \\
\hline & Cultured & 18.25 & 18.23 & 18.23 & 19.20 & 16.33 & 18.67 & 19.77 \\
\hline \multirow[b]{2}{*}{$16: 1$} & Wild & $5.27 \pm 0.10^{\mathrm{a}}$ & $5.30 \pm 0.35^{\mathrm{a}}$ & $4.45 \pm 0.66^{\mathrm{a}}$ & $6.41 \pm 0.26^{\mathrm{a}}$ & $5.61 \pm 0.84^{\mathrm{a}}$ & $4.19 \pm 0.96^{\mathrm{a}}$ & $0.08 \pm 0.00^{\mathrm{a}}$ \\
\hline & Cultured & $5.65 \pm 0.36^{\mathrm{a}}$ & $5.33 \pm 0.49^{\mathrm{a}}$ & $5.37 \pm 0.07^{\mathrm{a}}$ & $4.26 \pm 0.65^{\mathrm{b}}$ & $4.74 \pm 0.62^{\mathrm{a}}$ & $5.10 \pm 0.50^{\mathrm{a}}$ & $2.69 \pm 0.06^{\mathrm{b}}$ \\
\hline \multirow{2}{*}{ 18:1 n9 } & Wild & $10.66 \pm 0.36^{\mathrm{a}}$ & $18.88 \pm 3.43^{\mathrm{a}}$ & $20.31 \pm 1.45^{\mathrm{a}}$ & $24.51 \pm 0.16^{\mathrm{a}}$ & $20.79 \pm 2.97^{\mathrm{a}}$ & $28.07 \pm 2.87^{\mathrm{a}}$ & $21.19 \pm 0.00^{\mathrm{a}}$ \\
\hline & Cultured & $30.47 \pm 1.4^{\mathrm{b}}$ & $29.25 \pm 2.00^{\mathrm{b}}$ & $29.08 \pm 1.70^{b}$ & $27.17 \pm 0.04^{\mathrm{b}}$ & $31.27 \pm 2.02^{\mathrm{b}}$ & $25.55 \pm 1.42^{\mathrm{a}}$ & $24.79 \pm 0.32^{b}$ \\
\hline \multirow{2}{*}{ Other fatty acids } & Wild & $1.24 \pm 0.01^{\mathrm{a}}$ & $0.36 \pm 0.01^{\mathrm{b}}$ & $1.00 \pm 0.01^{\mathrm{a}}$ & $0.48 \pm 0.04^{\mathrm{a}}$ & $0.36 \pm 0.03^{\mathrm{a}}$ & $1.78 \pm 0.04^{\mathrm{a}}$ & $1.52 \pm 0.01^{\mathrm{b}}$ \\
\hline & Cultured & $1.12 \pm 0.01^{\mathrm{a}}$ & $1.2 \pm 0.02^{\mathrm{a}}$ & $1.14 \pm 0.03^{\mathrm{a}}$ & $0.03 \pm 0.01^{\mathrm{b}}$ & $0.43 \pm 0.03^{\mathrm{a}}$ & $1.29 \pm 0.01^{\mathrm{b}}$ & $1.18 \pm 0.01^{\mathrm{a}}$ \\
\hline \multirow[b]{2}{*}{$\sum$ MUFA } & Wild & 17.18 & 24.60 & 25.87 & 31.41 & 26.77 & 34.06 & 22.80 \\
\hline & Cultured & 37.24 & 35.90 & 36.60 & 31.81 & 37.28 & 31.95 & 28.65 \\
\hline
\end{tabular}

Different letters $(a-b)$ in the same column show significant differences $(P<0.05)$.

Table 2. PUFA content of wild and cultured rainbow trout (\%).

\begin{tabular}{|c|c|c|c|c|c|c|c|c|}
\hline \multicolumn{9}{|c|}{ Storage time (days) } \\
\hline Fatty acids & Groups & 0 & 3 & 7 & 10 & 14 & 17 & 19 \\
\hline $18: 2 \mathrm{n} 6$ & $\begin{array}{l}\text { Wild } \\
\text { Cultured }\end{array}$ & $\begin{array}{l}0.11 \pm 0.00^{\mathrm{a}} \\
0.32 \pm 0.00^{\mathrm{b}}\end{array}$ & $\begin{array}{l}0.01 \pm 0.00^{\mathrm{a}} \\
0.01 \pm 0.00^{\mathrm{a}}\end{array}$ & $\begin{array}{l}0.02 \pm 0.00^{\mathrm{a}} \\
0.31 \pm 0.02^{\mathrm{b}}\end{array}$ & $\begin{array}{l}0.12 \pm 0.00^{\mathrm{a}} \\
0.01 \pm 0.00^{\mathrm{b}}\end{array}$ & $\begin{array}{l}0.07 \pm 0.00^{\mathrm{a}} \\
0.01 \pm 0.00^{\mathrm{b}}\end{array}$ & $\begin{array}{l}0.01 \pm 0.00^{\mathrm{a}} \\
0.01 \pm 0.00^{\mathrm{a}}\end{array}$ & $\begin{array}{l}0.12 \pm 0.00^{\mathrm{a}} \\
0.01 \pm 0.01^{\mathrm{b}}\end{array}$ \\
\hline $18: 3$ n6 & $\begin{array}{l}\text { Wild } \\
\text { Cultured }\end{array}$ & $\begin{array}{l}1.09 \pm 0.06^{\mathrm{a}} \\
0.22 \pm 0.00^{\mathrm{b}}\end{array}$ & $\begin{array}{l}0.17 \pm 0.02^{\mathrm{a}} \\
0.22 \pm 0.00^{\mathrm{a}}\end{array}$ & $\begin{array}{l}0.39 \pm 0.06^{\mathrm{a}} \\
0.24 \pm 0.01^{\mathrm{a}}\end{array}$ & $\begin{array}{l}0.37 \pm 0.09^{\mathrm{a}} \\
0.24 \pm 0.00^{\mathrm{a}}\end{array}$ & $\begin{array}{l}0.17 \pm 0.02^{\mathrm{a}} \\
0.24 \pm 0.00^{\mathrm{b}}\end{array}$ & $\begin{array}{l}0.18 \pm 0.01^{\mathrm{a}} \\
0.25 \pm 0.02^{\mathrm{b}}\end{array}$ & $\begin{array}{l}0.42 \pm 0.00^{\mathrm{a}} \\
0.22 \pm 0.01^{\mathrm{b}}\end{array}$ \\
\hline $18: 3$ n3 & $\begin{array}{l}\text { Wild } \\
\text { Cultured }\end{array}$ & $\begin{array}{l}0.31 \pm 0.12^{\mathrm{a}} \\
0.83 \pm 0.06^{\mathrm{b}}\end{array}$ & $\begin{array}{l}0.72 \pm 0.09^{\mathrm{a}} \\
0.69 \pm 0.08^{\mathrm{a}}\end{array}$ & $\begin{array}{l}0.52 \pm 0.00^{\mathrm{a}} \\
0.86 \pm 0.03^{\mathrm{b}}\end{array}$ & $\begin{array}{l}0.55 \pm 0.00^{\mathrm{a}} \\
0.71 \pm 0.00^{\mathrm{b}}\end{array}$ & $\begin{array}{l}0.35 \pm 0.04^{\mathrm{a}} \\
0.82 \pm 0.09^{\mathrm{b}}\end{array}$ & $\begin{array}{l}0.35 \pm 0.00^{\mathrm{a}} \\
0.73 \pm 0.07^{\mathrm{b}}\end{array}$ & $\begin{array}{l}0.65 \pm 0.00^{\mathrm{a}} \\
0.63 \pm 0.02^{\mathrm{a}}\end{array}$ \\
\hline $20: 2$ cis & $\begin{array}{l}\text { Wild } \\
\text { Cultured }\end{array}$ & $\begin{array}{l}0.60 \pm 0.35^{\mathrm{a}} \\
0.34 \pm 0.01^{\mathrm{a}}\end{array}$ & $\begin{array}{l}0.41 \pm 0.05^{\mathrm{a}} \\
0.35 \pm 0.01^{\mathrm{a}}\end{array}$ & $\begin{array}{l}0.33 \pm 0.01^{\mathrm{a}} \\
0.42 \pm 0.00^{\mathrm{a}}\end{array}$ & $\begin{array}{l}0.53 \pm 0.01^{\mathrm{a}} \\
0.84 \pm 0.07^{\mathrm{b}}\end{array}$ & $\begin{array}{l}1.17 \pm 0.21^{\mathrm{a}} \\
0.56 \pm 0.26^{\mathrm{b}}\end{array}$ & $\begin{array}{l}0.75 \pm 0.09^{\mathrm{a}} \\
0.35 \pm 0.02^{\mathrm{b}}\end{array}$ & $\begin{array}{l}0.56 \pm 0.02^{\mathrm{a}} \\
0.31 \pm 0.01^{\mathrm{b}}\end{array}$ \\
\hline $20: 3$ n6 & $\begin{array}{l}\text { Wild } \\
\text { Cultured }\end{array}$ & $\begin{array}{l}1.07 \pm 0.00^{\mathrm{a}} \\
0.54 \pm 0.07^{\mathrm{b}}\end{array}$ & $\begin{array}{l}0.81 \pm 0.05^{\mathrm{a}} \\
0.54 \pm 0.07^{\mathrm{a}}\end{array}$ & $\begin{array}{l}0.89 \pm 0.06^{\mathrm{a}} \\
0.52 \pm 0.02^{\mathrm{b}}\end{array}$ & $\begin{array}{l}1.13 \pm 0.04^{\mathrm{a}} \\
0.55 \pm 0.01^{\mathrm{b}}\end{array}$ & $\begin{array}{l}1.32 \pm 0.10^{\mathrm{a}} \\
0.51 \pm 0.01^{\mathrm{b}}\end{array}$ & $\begin{array}{l}1.12 \pm 0.19^{\mathrm{a}} \\
0.55 \pm 0.09^{\mathrm{b}}\end{array}$ & $\begin{array}{l}1.44 \pm 0.00^{\mathrm{a}} \\
0.57 \pm 0.02^{\mathrm{b}}\end{array}$ \\
\hline $20: 4$ n6 & $\begin{array}{l}\text { Wild } \\
\text { Cultured }\end{array}$ & $\begin{array}{l}1.28 \pm 0.00^{\mathrm{a}} \\
0.11 \pm 0.06^{\mathrm{b}}\end{array}$ & $\begin{array}{l}0.23 \pm 0.03^{\mathrm{a}} \\
0.25 \pm 0.02^{\mathrm{a}}\end{array}$ & $\begin{array}{l}0.26 \pm 0.01^{\mathrm{a}} \\
0.25 \pm 0.00^{\mathrm{a}}\end{array}$ & $\begin{array}{l}0.31 \pm 0.00^{\mathrm{a}} \\
0.27 \pm 0.00^{\mathrm{a}}\end{array}$ & $\begin{array}{l}0.26 \pm 0.08^{\mathrm{a}} \\
0.25 \pm 0.01^{\mathrm{a}}\end{array}$ & $\begin{array}{l}0.24 \pm 0.02^{\mathrm{a}} \\
0.26 \pm 0.01^{\mathrm{a}}\end{array}$ & $\begin{array}{l}0.31 \pm 0.00^{\mathrm{a}} \\
0.25 \pm 0.00^{\mathrm{a}}\end{array}$ \\
\hline $20: 5 \mathrm{n} 3$ & $\begin{array}{l}\text { Wild } \\
\text { Cultured }\end{array}$ & $\begin{array}{r}11.11 \pm 0.0^{\mathrm{a}} \\
2.16 \pm 0.11^{\mathrm{b}}\end{array}$ & $\begin{array}{l}4.40 \pm 0.22^{\mathrm{a}} \\
3.61 \pm 0.07^{\mathrm{b}}\end{array}$ & $\begin{array}{l}5.15 \pm 0.66^{\mathrm{a}} \\
3.68 \pm 0.01^{\mathrm{b}}\end{array}$ & $\begin{array}{l}3.75 \pm 0.00^{\mathrm{a}} \\
3.65 \pm 0.70^{\mathrm{a}}\end{array}$ & $\begin{array}{l}3.46 \pm 0.15^{\mathrm{a}} \\
3.73 \pm 0.17^{\mathrm{a}}\end{array}$ & $\begin{array}{l}2.98 \pm 0.35^{\mathrm{a}} \\
3.47 \pm 0.00^{\mathrm{b}}\end{array}$ & $\begin{array}{l}3.90 \pm 0.01^{\mathrm{a}} \\
3.41 \pm 0.02^{\mathrm{a}}\end{array}$ \\
\hline $22: 6 \mathrm{n} 3$ & $\begin{array}{l}\text { Wild } \\
\text { Cultured }\end{array}$ & $\begin{array}{l}18.56 \pm 1.3^{\mathrm{a}} \\
10.29 \pm 2.4^{\mathrm{b}}\end{array}$ & $\begin{array}{l}19.82 \pm 2.00^{\mathrm{a}} \\
12.52 \pm 3.04^{\mathrm{b}}\end{array}$ & $\begin{array}{l}16.59 \pm 0.10^{\mathrm{a}} \\
11.71 \pm 2.00^{\mathrm{b}}\end{array}$ & $\begin{array}{l}14.74 \pm 0.65^{\mathrm{a}} \\
13.57 \pm 0.77^{\mathrm{a}}\end{array}$ & $\begin{array}{l}23.72 \pm 1.04^{\mathrm{a}} \\
11.27 \pm 0.77^{\mathrm{b}}\end{array}$ & $\begin{array}{l}18.48 \pm 1.08^{\mathrm{a}} \\
12.13 \pm 2.45^{\mathrm{b}}\end{array}$ & $\begin{array}{l}11.65 \pm 0.01^{\mathrm{a}} \\
13.75 \pm 0.53^{\mathrm{b}}\end{array}$ \\
\hline Other fatty acids & $\begin{array}{l}\text { Wild } \\
\text { Cultured }\end{array}$ & $\begin{array}{c}- \\
0.03 \pm 0.01^{\mathrm{a}}\end{array}$ & $\begin{array}{l}0.14 \pm 0.04^{\mathrm{a}} \\
0.04 \pm 0.00^{\mathrm{b}}\end{array}$ & $\begin{array}{l}0.10 \pm 0.00^{\mathrm{a}} \\
0.04 \pm 0.00^{\mathrm{b}}\end{array}$ & $\begin{array}{l}0.13 \pm 0.00^{\mathrm{a}} \\
0.03 \pm 0.00^{\mathrm{b}}\end{array}$ & $\begin{array}{l}0.16 \pm 0.02^{\mathrm{a}} \\
0.04 \pm 0.00^{\mathrm{b}}\end{array}$ & $\begin{array}{l}0.17 \pm .0 .02^{\mathrm{a}} \\
0.04 \pm 0.00^{\mathrm{b}}\end{array}$ & $\begin{array}{l}0.18 \pm 0.00^{\mathrm{a}} \\
0.04 \pm 0.00^{\mathrm{b}}\end{array}$ \\
\hline$\sum$ PUFA & $\begin{array}{l}\text { Wild } \\
\text { Cultured }\end{array}$ & $\begin{array}{l}15.57 \\
14.87\end{array}$ & $\begin{array}{l}26.72 \\
18.25\end{array}$ & $\begin{array}{l}24.26 \\
18.06\end{array}$ & $\begin{array}{l}21.65 \\
19.88\end{array}$ & $\begin{array}{l}30.69 \\
17.44\end{array}$ & $\begin{array}{l}24.29 \\
17.81\end{array}$ & $\begin{array}{l}19.24 \\
19.21\end{array}$ \\
\hline
\end{tabular}

Different letters $(\mathrm{a}-\mathrm{b})$ in the same column show significant differences $(P<0.05)$.

(C16:1), stearic acid (C18:0), oleic acid (C18:1 n-9), cis5,8,11,14,17-eicosapentaenoic acid (EPA. C20:5n-3) and cis4,7,10,13,16,19-docosahexaenoic acid (DHA, C22:6 n-3). These results are in agreement with previous studies on fatty acids of freshwater fish (Ozogul et al., 2007). It was observed that the proportion of these fatty acids changed throughout storage period. The results showed that wild fish are very rich in n-3 polyunsaturated fatty acids (PUFA). Similar results were reported for wild rainbow trout by Fallah et al. (2011).

The levels of saturated fatty acids (SFA) between wild and cultured rainbow trout during storage period did not vary. However, Haliloğlu et al. (2001) reported significant differences in the level of SFA among three different trout species (Salvelinus alpinus. Salmo trutta fario ve Oncorhyn- 
chus mykiss) fed the same diet. O. mykiss had the highest SFA content $(31.92 \%)$ whereas Salmo trutta fario had the lowest SFA content.

Blanchet et al. (2005) reported that cultured rainbow trout had higher lipid level and lower n-3 PUFA than wild rainbow trout. Vliet and Katan (1990) found that the ratio of n-3 to n-6 PUFA was significantly lower in cultured than in wild trout, eel and salmon. Hunted fish are a better source of n-3 PUFA than are cultured fish. Grigorakis et al. (2002) reported that cultured gilthead sea bream were characterized by higher levels of monoenes, n-9 and C18:2n-6 fatty acids and wild gilthead sea bream by higher levels of saturates, C20:4n-6, n-3 fatty acids and n-3/n-6 ratios. In this study, wild rainbow trout contained higher lipid level and higher level of n-3 PUFA than cultured rainbow trout. Although SFA and PUFA contents of wild rainbow trout were higher than cultured, monounsaturated fatty acids (MUFA) was the highest in cultured fish.

Sensory analyses Sensory analyses of raw wild and cultured rainbow trout are given in Figure 1. Although there
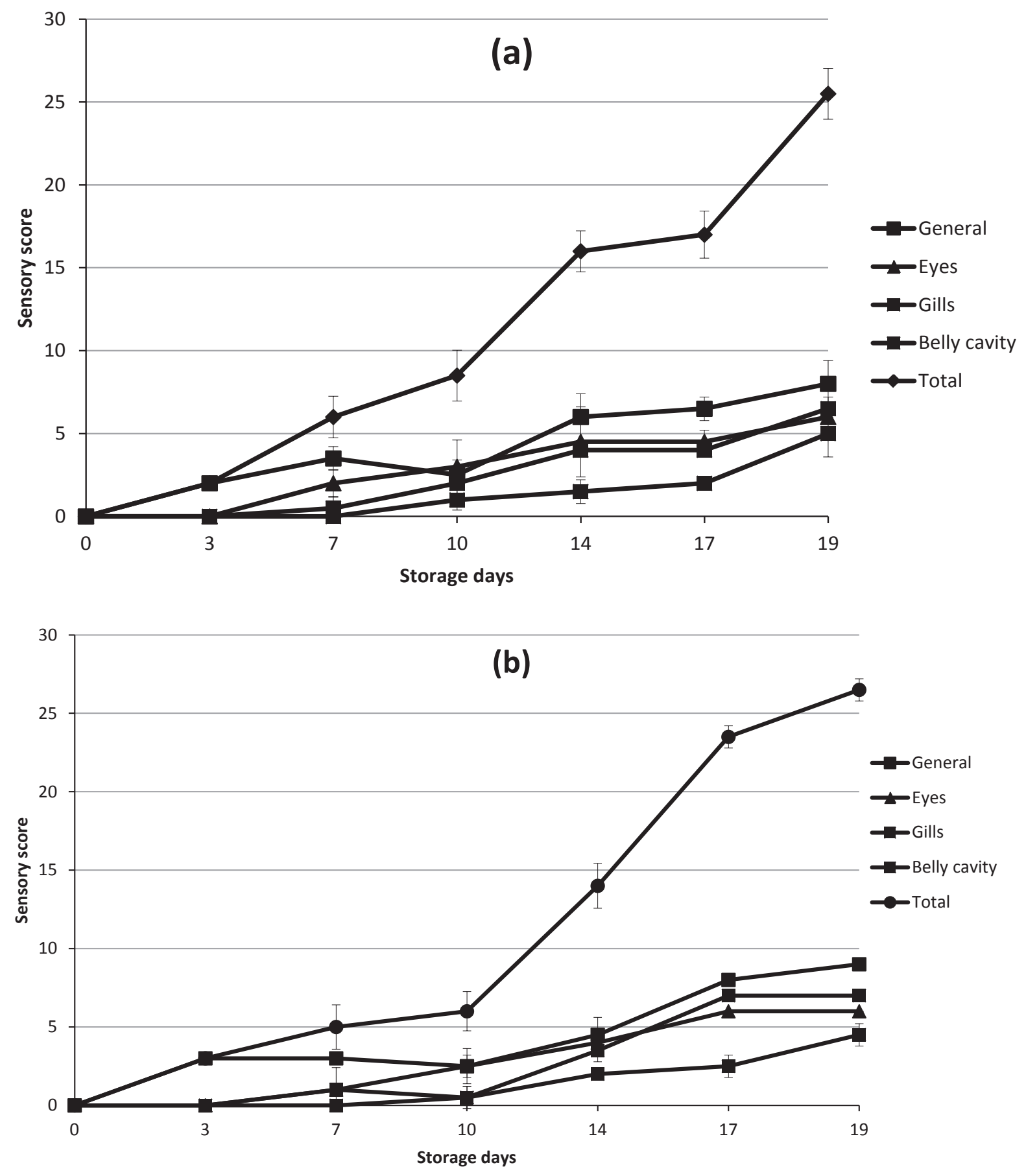

Fig. 1. Sensory analysis of raw wild (a) and cultured (b) trout during storage at $4^{\circ} \mathrm{C}$. 
were no significant differences between wild and cultured trout at the beginning of storage period, significant differences were observed as storage time progress $(p<0.05)$. Although wild fish were preferred to cultured fish due to the taste and flavor, shelf life of both wild and cultured rainbow trout was 14 days with demerit scores of 16 and 14 , respectively. Similar results were obtained for cultured rainbow trout (Ozogul and Ozogul, 2004). Chytiri et al. (2004) reported shelf life of cultured rainbow trout in ice was 15 - 16 days for ungutted rainbow trout and $10-12$ days for rainbow trout fillets. Wunnenberg and Oehlenschläger (2008) found that shelf life of iced wild rainbow trout in autumn was 14 days and 16 days for rainbow trout caught in winter, spring and summer. However, Rezaei et al. (2007) reported 9 - 11 days of shelf life for iced wild rainbow trout.

Sensory analyses of cooked wild and cultured rainbow trout are given in Figure 2. The sensory score for flavour of the cooked fillets decreased with storage time. The fresh flavour characteristics of the species were strong between 0 and 10 days. Off-flavours and off-odours were detected on 17 days of storage trial due to bacterial metabolites. The rejection point for the cooked fillets was below 5 at 19 days. Similar results were obtained for cultured rainbow trout (Chytiri et al., 2004). In the case of sea bream, farmed specimens have a softer texture and less robust flavor, thus consumers prefer farmed fish from the wild (Alasalvar et al., 2002;
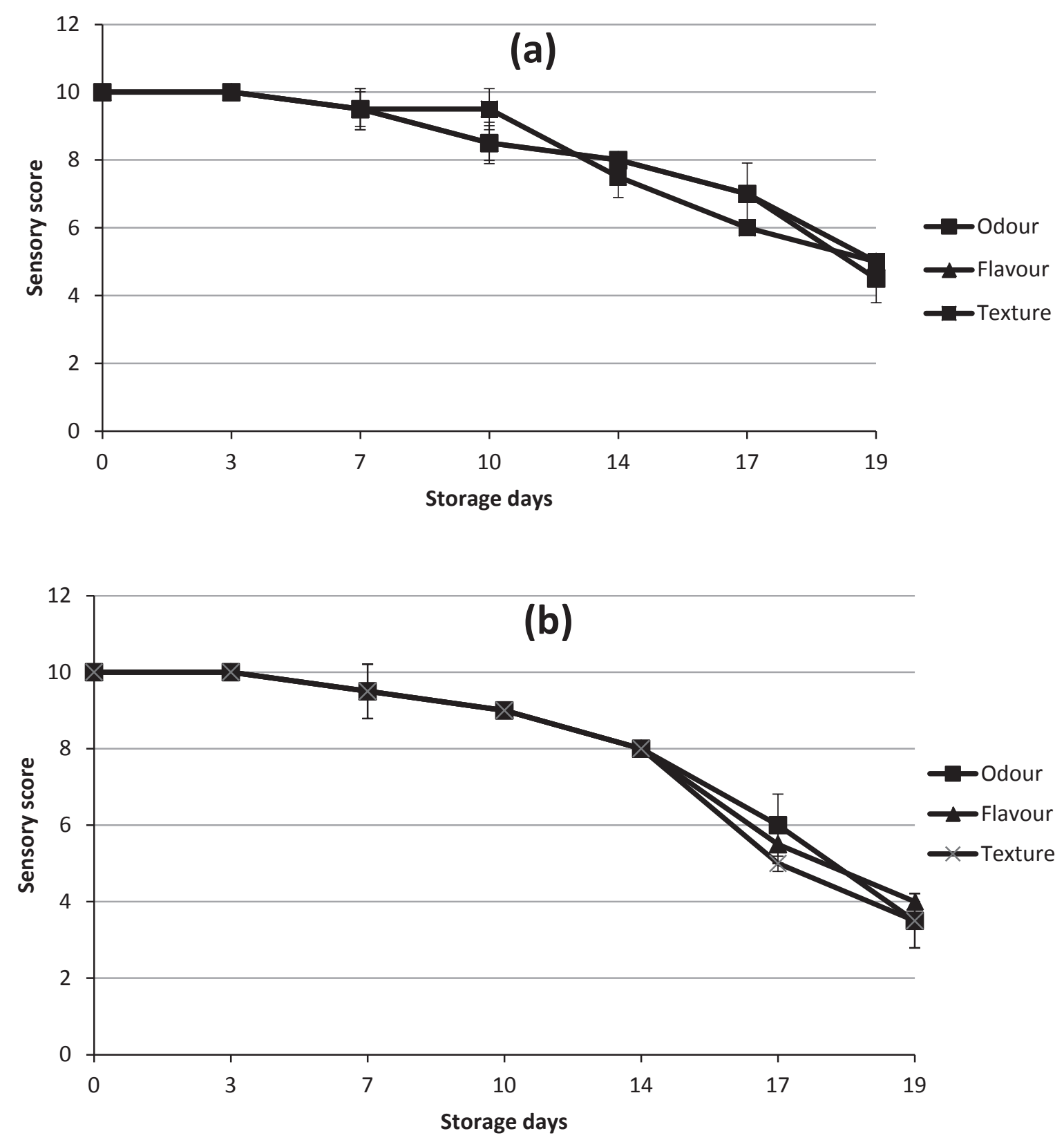

Fig. 2. Sensory analysis of cooked wild (a) and cultured (b) trout during storage at $4^{\circ} \mathrm{C}$. 
Grigorakis et al., 2003).

Chemical analyses TVB-N contains mainly ammonia, trimethylamine (TMA) and dimethylamine (DMA), the levels of which increase with spoilage by either bacterial or enzymic degradation (Ozogul and Ozogul 2000). The TVB-N content ranged from $11.15-28.56 \mathrm{mg} / 100 \mathrm{~g}$ for wild rainbow trout and from $10.46-16.35 \mathrm{mg} / 100 \mathrm{~g}$ for cultured rainbow trout (Table 3). Chytiri et al. (2004) found that the TVB-N content ranged from 14.11 to $20.16 \mathrm{mg} \mathrm{N} / 100 \mathrm{~g}$ flesh for whole ungutted and from 18.11 - 26.06 for filleted trout samples, respectively, during the 18 day period of storage in ice. The levels of $30-35 \mathrm{mg} \mathrm{N}$ per $100 \mathrm{~g}$ muscle are considered the limit of acceptability for ice-stored cold water fish (Huss 1988; Connell 1995) or $35 \mathrm{mg} \mathrm{N} / 100 \mathrm{~g}$ flesh for raw fish according to EC guidelines (EC Directive 95. 149). However, Gimenez et al. (2002) proposed a value of $25 \mathrm{mg}$ $\mathrm{N} / 100 \mathrm{~g}$ flesh as the highest acceptable level for rainbow trout. In the current study, all TVB-N values remained below these limit of acceptability during storage period in ice with the exception of wild rainbow trout for which a value of $28.56 \mathrm{mg} / 100 \mathrm{~g}$ flesh was recorded on day 17 of storage (Table 3). TVB-N is produced mainly by bacterial decomposition of fish flesh. Therefore, the higher values of TVC after 14 days of storage in ice could account for the higher TVB$\mathrm{N}$ values of fish samples. TVB-N values showed significant fluctuation for wild and cultured fish as reported by Chytiri et al. (2004) for both whole and filleted trout samples, indicating that TVB-N is a poor indicator of fish freshness (Dawood et al., 1986; Kyrana et al., 1997; Tejada and Huidobro, 2002; Rezaei and Hosseini, 2008; Rezaei et al., 2007).

TBA is secondary oxidation products and widely used as an indicator of degree of lipid oxidation (Nishimoto et al., 1985). TBA values of wild and cultured rainbow trout are given in Table 3. TBA values showed significant fluctuation for wild and cultured fish. Chytiri et al. (2004) reported that TBA values increased throughout storage period for filleted and ungutted rainbow trout. Present results indicated that oxidative rancidity remained relatively high in wild and cultured rainbow trout. TBA values may not reveal the actual degree of lipid oxidation since MA can interact with other components of fish body. Such components may be amines, nucleosides, nucleic acid, proteins, phospholipids and other aldehydes that are end products of lipid oxidation. Such interactions may vary greatly with fish species (Auburg, 1993). Slightly higher TBA values for wild samples are probably due to the high content of lipid and unsaturated fatty acids that affects rancidity levels of fish samples.

Shelf life of oily fish species is limited due to the oxidation of lipid. Table 3 shows the peroxide value of wild and cultured rainbow trout during storage of 19 days. There were no significant differences $(p>0.05)$ in PV values between wild and cultured samples. The initial PV was 9.0 meqO$_{2}$ $\mathrm{kg}^{-1}$ for wild rainbow trout and $10.35 \mathrm{meqO}_{2} \mathrm{~kg}^{-1}$ for cultured rainbow trout and then increased to $14.91 \mathrm{meqO}_{2} \mathrm{~kg}^{-1}$ and $12.16 \mathrm{meqO}_{2} \mathrm{~kg}^{-1}$ at 3 days, respectively. After that, its level decreased in both samples. This could be explained as results of increase in the level of TBA for secondary breakdown product of lipid oxidation. After 7 days of storage, PV showed fluctuations for the rest of storage period. However, $\mathrm{PV}$ remained below the maximum recommended value for human consumption $\left(20 \mathrm{meqO}_{2} \mathrm{~kg}^{-1}\right)$. Rezaei and Hosseini (2008) reported a marked increase $(P<0.05)$ in PV from the initial value of 1.17 to $6.25 \mathrm{meq} / \mathrm{kg}$ for iced farmed rainbow trout.

Changes in FFA values of wild and cultured rainbow trout are given in Table 3. The initial level of FFA was 5.9\% for wild rainbow trout and $4.59 \%$ for cultured rainbow trout, reaching maximum level of $11.04 \%$ and $10.26 \%$. respectively, at the end of the storage period. There were significant differences $(p<0.05)$ in FFA between wild and cultured rainbow trout. The lower FFA was observed for cultured than wild samples. Lipid hydrolysis developed at a slower rate in the cultured samples. Rezaei and Hosseini (2008) reported that initial FFA value in iced farmed rainbow trout was $1.5 \%$

Table 3. Changes in TVBN, TBA, PV and FFA values of wild and raw rainbow trout during the storage at $4^{\circ} \mathrm{C}$.

\begin{tabular}{|c|c|c|c|c|c|c|c|c|}
\hline \multirow{2}{*}{$\begin{array}{l}\text { Storage time } \\
\text { (days) }\end{array}$} & \multicolumn{2}{|c|}{ TVBN (mg/100g) } & \multicolumn{2}{|c|}{$\mathrm{TBA}(\mathrm{mg} / \mathrm{kg})$} & \multicolumn{2}{|c|}{$\mathrm{PV}\left(\mathrm{meqO}_{2} / \mathrm{kg}\right)$} & \multicolumn{2}{|c|}{ FFA $(\%$ oleic acid $)$} \\
\hline & Wild & Cultured & Wild & Cultured & Wild & Cultured & Wild & Cultured \\
\hline 0 & $11.15^{\mathrm{e}} \pm 0.02$ & $14.13^{\mathrm{e}} \pm 0.80$ & $1.37^{\mathrm{b}} \pm 0.19$ & $0.96^{\mathrm{a}} \pm 0.03$ & $9.00^{\mathrm{b}} \pm 0.26$ & $10.35^{\mathrm{bc}} \pm 0.26$ & $5.9^{\mathrm{bc}} \pm 0.48$ & $4.59^{b c} \pm 0.39$ \\
\hline 3 & $14.97^{\mathrm{cd}} \pm 0.54$ & $16.35^{\mathrm{a}} \pm 0.50$ & $0.89^{c} \pm 0.04$ & $0.87^{\mathrm{b}} \pm 0.04$ & $14.91^{\mathrm{a}} \pm 0.71$ & $12.16^{\mathrm{a}} \pm 0.43$ & $6.15^{\mathrm{b}} \pm 0.42$ & $6.01^{\mathrm{b}} \pm 0.21$ \\
\hline 7 & $14.41^{\mathrm{d}} \pm 1.02$ & $15.48^{\mathrm{ab}} \pm 1.67$ & $0.48^{\mathrm{d}} \pm 0.02$ & $0.51^{\mathrm{d}} \pm 0.04$ & $4.12^{\mathrm{e}} \pm 0.15$ & $5.14^{\mathrm{e}} \pm 0.13$ & $5.09^{\mathrm{cd}} \pm 0.42$ & $4.08^{c} \pm 0.35$ \\
\hline 10 & $12.20^{\mathrm{e}} \pm 0.53$ & $10.46^{\mathrm{b}} \pm 0.96$ & $0.81^{\mathrm{c}} \pm 0.02$ & $0.72^{\mathrm{c}} \pm 0.06$ & $7.18^{\mathrm{c}} \pm 0.40$ & $9.78^{c} \pm 0.33$ & $4.77^{\mathrm{d}} \pm 0.24$ & $3.66^{\mathrm{c}} \pm 0.23$ \\
\hline 14 & $16.21^{\mathrm{bc}} \pm 0.77$ & $15.48^{\mathrm{ab}} \pm 0.22$ & $0.88^{\mathrm{c}} \pm 0.18$ & $0.86^{\mathrm{b}} \pm 0.04$ & $6.07^{\mathrm{d}} \pm 0.24$ & $4.47^{\mathrm{e}} \pm 0.03$ & $5.26^{\mathrm{cd}} \pm 0.29$ & $4.31^{c} \pm 0.07$ \\
\hline 17 & $28.56^{\mathrm{a}} \pm 0.92$ & $11.68^{b} \pm 0.28$ & $2.08^{\mathrm{a}} \pm 0.35$ & $0.75^{\mathrm{c}} \pm 0.06$ & $7.12^{\mathrm{cd}} \pm 0.66$ & $7.54^{\mathrm{d}} \pm 0.56$ & $6.51^{\mathrm{b}} \pm 0.01$ & $4.36^{\mathrm{c}} \pm 0.40$ \\
\hline 19 & $17.08^{b} \pm 0.59$ & $14.48^{\mathrm{ab}} \pm 0.28$ & $0.21^{\mathrm{e}} \pm 0.12$ & $0.84^{\mathrm{b}} \pm 0.05$ & $8.98^{\mathrm{b}} \pm 0.37$ & $10.6^{\mathrm{b}} \pm 0.21$ & $11.04^{\mathrm{a}} \pm 0.21$ & $10.26^{\mathrm{a}} \pm 1.59$ \\
\hline
\end{tabular}

$\overline{\mathrm{X}}=\mathrm{S}_{\overline{\mathrm{X}}}$ : Mean value \pm Standard deviation. Different letters $(\mathrm{a}-\mathrm{e})$ in the same row show significant differences $(P<0.05)$. 
and its level increased to $2.89 \%$ after 20 days of storage.

Biogenic amines The detection of biogenic amines has become important in recent years as an indicator of food quality. Biogenic amines are non-volatile amines formed by decarboxylation of amino acids. Although many biogenic amines have been found in fish, only histamine, cadaverine, and putrescine have been found to be significant in fish safety and quality determination (Al Bulushia et al., 2009). The most common poisoning is due to the histamine, known as scombroid fish poisoning. Secondary amines such as putrescine and cadaverine play an important role in food poisoning as they can potentiate the toxicity of histamine and react with nitrites to form nitrosamines, which are carcinogenic compounds (Cinquinaa et al., 2004). The relationship between biogenic amines, sensory evaluation, and trimethylamine during spoilage are influenced by bacterial composition and free amino acid content. A mesophilic bacterial count of $\log$ $6-7 \mathrm{cfu} / \mathrm{g}$ has been found to be associated with $5 \mathrm{mg}$ histamine/100 $\mathrm{g}$ fish, the Food and Drug Administration (FDA 1996) maximum allowable histamine level.

Table 4 shows the biogenic amine and TMA contents of wild and cultured rainbow trout. There were significant differences $(p<0.05)$ in ammonia, TMA and biogenic amine contens of wild and cultured rainbow trout. In the present study, histamine produced by bacterial decarboxylation of free histidine (Fernandez-Salguero and Mackie, 1979) was not detected in any samples throughout the storage period apart from wild rainbow trout at 7 days of storage. Its level remained lower $(0.5 \mathrm{mg} / \mathrm{kg})$ than the limit value $(5 \mathrm{mg}$ histamine/100 $\mathrm{g}$ fish by FDA). Histamine was not detected as found in previous studies (Ozogul et al., 2006; Rezaei et al., 2007). Ozogul et al. (2006) reported that the level of biogenic amines, regardless of the diet treatment, showed a similar trend. They also reported that diet ingredients did not have any effect on the biogenic amine content of cultured rainbow trout in ice although lower biogenic amine values were obtained from trout stored in modified atmosphere package
(MAP)/ice. The biogenic amine content of fish depends on fish species, the presence of decarboxylase-active microorganisms and the availability of free amino acids (Mackie et al., 1997; Bodmer et al., 1999), the moment of capture and stomach contents at death since microbial flora vary seasonally (Rodriguez et al., 1999), aquaculture conditions, food (which affects microbes), body composition, and storage and processing conditions (Krizek et al., 2004; Shahidi and Botta, 1994).

As storage time progressed, putrescine, tryptamine, tyramine, serotonin and dopamine became the dominant amines and their concentrations showed fluctuations during storage period. The initial putrescine level was $6.10 \mathrm{mg} / 100 \mathrm{~g}$ and increased to maximum level of $12.82 \mathrm{mg} / 100 \mathrm{~g}$ at 10 days whereas cadaverine was detected after 3 days of storage and increased to $7.13 \mathrm{mg} / 100 \mathrm{~g}$ at the end of storage period. The levels of other biogenic amines fluctuated during the storage period. The biogenic amine (BA) content of whole and filleted rainbow trout was monitored during ice storage for a period of 18 days (Chytiri et al., 2004). Of the BAs determined, concentration of putrescine, cadaverine, spermidine, tryptamine, and $\beta$-phenylethylamine increased steeply in both whole and filleted trout between days 15 and 18 of storage when pseudomonads and $\mathrm{H}_{2} \mathrm{~S}$-producing bacteria reached approximately $10^{6}$ to $10^{7} \mathrm{CFU} / \mathrm{g}$. A putrescine value of 13 to $14 \mathrm{mg} / \mathrm{kg}$ and a spermidine value of approximately 7 $\mathrm{mg} / \mathrm{kg}$ for both the whole and filleted trout obtained after 12 and 9 days, respectively, may be proposed as the upper limit for spoilage initiation (freshness indicator) of fresh rainbow trout based on sensorial and microbiological (total viable count of $10^{6}$ to $10^{7}$ ) data. Rezaei et al. (2007) investigated the biogenic amine content and related bacterial changes (Pseudomonas spp., psychrotrophic and mesophilic counts) in whole farmed rainbow trout during ice storage for 18 days. Levels of putrescine, cadaverine and histamine, and bacterial loads, increased $(P<0.05)$ during storage, but tyramine was not detected in any of the tested samples. Concentration

Table 4. Changes in biogenic amines content of wild and raw rainbow trout during the storage at $4^{\circ} \mathrm{C}$.

\begin{tabular}{|c|c|c|c|c|c|c|c|c|c|c|c|c|c|c|}
\hline Days & AMN & PUT & KAD & SPD & TRP & PHEN & SPN & HIS & SER & TYR & TMA & DOP & $\mathrm{AGM}$ & Groups \\
\hline 0 & $\begin{array}{l}11.16 \pm 0.82^{\mathrm{a}} \\
16.99 \pm 0.90^{\mathrm{b}}\end{array}$ & $\begin{array}{l}6.10 \pm 0.56^{\mathrm{a}} \\
1.44 \pm 0.01^{\mathrm{b}}\end{array}$ & $\begin{array}{l}0.00 \pm 0.00^{\mathrm{a}} \\
0.00 \pm 0.00^{\mathrm{a}}\end{array}$ & $\begin{array}{l}1.82 \pm 0.14^{\mathrm{a}} \\
2.54 \pm 0.27^{\mathrm{a}}\end{array}$ & $\begin{array}{l}2.00 \pm 0.11^{\mathrm{a}} \\
0.01 \pm 0.01^{\mathrm{b}}\end{array}$ & $\begin{array}{l}0.00 \pm 0.00^{\mathrm{a}} \\
0.21 \pm 0.00^{\mathrm{b}}\end{array}$ & $\begin{array}{l}1.41 \pm 0.03^{\mathrm{a}} \\
3.74 \pm 0.80^{\mathrm{b}}\end{array}$ & $\begin{array}{l}0.00 \pm 0.00^{\mathrm{a}} \\
0.00 \pm 0.00^{\mathrm{a}}\end{array}$ & $\begin{array}{l}8.47 \pm 0.66^{\mathrm{a}} \\
8.18 \pm 0.56^{\mathrm{a}}\end{array}$ & $\begin{array}{l}12.39 \pm 0.82^{\mathrm{a}} \\
11.23 \pm 0.88^{\mathrm{a}}\end{array}$ & $\begin{array}{l}0.52 \pm 0.03^{\mathrm{a}} \\
0.04 \pm 0.00^{\mathrm{b}}\end{array}$ & $\begin{array}{l}4.27 \pm 0.39^{\mathrm{a}} \\
3.83 \pm 0.42^{\mathrm{b}}\end{array}$ & $\begin{array}{l}1.44 \pm 0.05^{\mathrm{a}} \\
1.15 \pm 0.12^{\mathrm{a}}\end{array}$ & $\begin{array}{l}\text { Wild } \\
\text { Cultured }\end{array}$ \\
\hline 3 & $\begin{array}{l}1.77 \pm 0.14^{\mathrm{a}} \\
7.12 \pm 0.32^{\mathrm{b}}\end{array}$ & $\begin{array}{l}2.41 \pm 0.24^{\mathrm{a}} \\
2.27 \pm 0.23^{\mathrm{a}}\end{array}$ & $\begin{array}{l}0.63 \pm 0.09^{\mathrm{a}} \\
0.13 \pm 0.00^{\mathrm{b}}\end{array}$ & $\begin{array}{l}2.86 \pm 0.20^{\mathrm{a}} \\
3.13 \pm 0.13^{\mathrm{b}}\end{array}$ & $\begin{array}{l}0.93 \pm 1.02^{\mathrm{a}} \\
1.88 \pm 0.16^{\mathrm{b}}\end{array}$ & $\begin{array}{l}0.32 \pm 0.03^{\mathrm{a}} \\
0.49 \pm 0.03^{\mathrm{b}}\end{array}$ & $\begin{array}{l}2.46 \pm 0.06^{\mathrm{a}} \\
4.74 \pm 0.39^{\mathrm{b}}\end{array}$ & $\begin{array}{l}0.00 \pm 0.00^{\mathrm{a}} \\
0.08 \pm 0.00^{\mathrm{b}}\end{array}$ & $\begin{array}{l}4.40 \pm 0.21^{\mathrm{a}} \\
19.5 \pm 0.76^{\mathrm{b}}\end{array}$ & $\begin{array}{c}8.22 \pm 0.18^{\mathrm{a}} \\
56.13 \pm 4.38^{\mathrm{b}}\end{array}$ & $\begin{array}{l}0.04 \pm 0.00^{\mathrm{a}} \\
0.05 \pm 0.00^{\mathrm{a}}\end{array}$ & $\begin{array}{c}4.33 \pm 0.19^{\mathrm{a}} \\
17.54 \pm 0.46^{\mathrm{b}}\end{array}$ & $\begin{array}{l}2.13 \pm 0.12^{\mathrm{a}} \\
0.45 \pm 0.00^{\mathrm{b}}\end{array}$ & $\begin{array}{l}\text { Wild } \\
\text { Cultured }\end{array}$ \\
\hline 7 & $\begin{array}{c}11.04 \pm 1.19^{\mathrm{a}} \\
9.48 \pm 0.15^{\mathrm{b}}\end{array}$ & $\begin{array}{l}3.26 \pm 0.32^{\mathrm{a}} \\
1.73 \pm 0.01^{\mathrm{b}}\end{array}$ & & $\begin{array}{l}2.40 \pm 0.14^{\mathrm{a}} \\
2.33 \pm 0.13^{\mathrm{a}}\end{array}$ & $\begin{array}{l}5.20 \pm 0.05^{\mathrm{a}} \\
2.57 \pm 0.08^{\mathrm{b}}\end{array}$ & $\begin{array}{l}0.00 \pm 0.00^{\mathrm{a}} \\
0.02 \pm 0.00^{\mathrm{a}}\end{array}$ & $\begin{array}{l}2.57 \pm 0.22^{\mathrm{a}} \\
2.78 \pm 0.13^{\mathrm{a}}\end{array}$ & $\begin{array}{l}0.50 \pm 0.00^{\mathrm{a}} \\
0.00 \pm 0.00^{\mathrm{b}}\end{array}$ & $\begin{array}{l}15.69 \pm 1.18^{\mathrm{a}} \\
12.73 \pm 1.00^{\mathrm{b}}\end{array}$ & $\begin{array}{l}15.36 \pm 0.43^{\mathrm{a}} \\
35.96 \pm 1.45^{\mathrm{b}}\end{array}$ & $\begin{array}{l}0.05 \pm 0.00^{\mathrm{a}} \\
0.04 \pm 0.00^{\mathrm{a}}\end{array}$ & & & $\begin{array}{l}\text { Wild } \\
\text { Cultured }\end{array}$ \\
\hline 10 & $\begin{array}{l}1.76 \pm 0.18^{\mathrm{a}} \\
2.20 \pm 0.17^{\mathrm{a}}\end{array}$ & $\begin{array}{l}12.82 \pm 1.51^{\mathrm{a}} \\
4.62 \pm 0.00^{\mathrm{b}}\end{array}$ & $\begin{array}{l}0.54 \pm 0.06^{\mathrm{a}} \\
0.00 \pm 0.00^{\mathrm{b}}\end{array}$ & $\begin{array}{l}2.85 \pm 0.04^{\mathrm{a}} \\
5.41 \pm 1.30^{\mathrm{b}}\end{array}$ & $\begin{array}{l}0.05 \pm 0.01^{\mathrm{a}} \\
0.00 \pm 0.00^{\mathrm{a}}\end{array}$ & $\begin{array}{l}0.66 \pm 0.04^{\mathrm{a}} \\
0.68 \pm 0.01^{\mathrm{a}}\end{array}$ & $\begin{array}{l}2.46 \pm 0.06^{\mathrm{a}} \\
5.32 \pm 0.48^{\mathrm{b}}\end{array}$ & $\begin{array}{l}0.00 \pm 0.00^{\mathrm{a}} \\
0.05 \pm 0.00^{\mathrm{b}}\end{array}$ & $\begin{array}{c}13.97 \pm 0.59^{\mathrm{a}} \\
5.03 \pm 0.01^{\mathrm{b}}\end{array}$ & $\begin{array}{l}22.97 \pm 1.36^{\mathrm{a}} \\
22.26 \pm 1.78^{\mathrm{a}}\end{array}$ & $\begin{array}{l}0.05 \pm 0.00^{\mathrm{a}} \\
0.04 \pm 0.00^{\mathrm{a}}\end{array}$ & $\begin{array}{l}11.02 \pm 2.19^{\mathrm{a}} \\
17.11 \pm 0.98^{\mathrm{b}}\end{array}$ & $\begin{array}{l}0.53 \pm 0.03^{\mathrm{a}} \\
1.51 \pm 0.12^{\mathrm{b}}\end{array}$ & $\begin{array}{l}\text { Wild } \\
\text { Cultured }\end{array}$ \\
\hline 14 & $\begin{array}{l}2.66 \pm 0.14^{\mathrm{a}} \\
3.37 \pm 0.25^{\mathrm{b}}\end{array}$ & $\begin{array}{l}1.89 \pm 0.12^{\mathrm{a}} \\
2.69 \pm 0.18^{\mathrm{b}}\end{array}$ & $\begin{array}{l}2.27 \pm 0.17^{\mathrm{a}} \\
0.00 \pm 0.00^{\mathrm{b}}\end{array}$ & $\begin{array}{l}1.58 \pm 0.18^{\mathrm{a}} \\
3.08 \pm 0.35^{\mathrm{b}}\end{array}$ & $\begin{array}{l}0.03 \pm 0.00^{\mathrm{a}} \\
11.9 \pm 1.25^{\mathrm{b}}\end{array}$ & $\begin{array}{l}0.44 \pm 0.01^{\mathrm{a}} \\
0.54 \pm 0.07^{\mathrm{a}}\end{array}$ & $\begin{array}{l}1.96 \pm 0.19^{\mathrm{a}} \\
3.64 \pm 1.24^{\mathrm{b}}\end{array}$ & $\begin{array}{l}0.00 \pm 0.00^{\mathrm{a}} \\
0.00 \pm 0.00^{\mathrm{a}}\end{array}$ & $\begin{array}{c}10.89 \pm 0.74^{\mathrm{a}} \\
11.25 \pm 1.8^{\mathrm{a}}\end{array}$ & $\begin{array}{l}24.71 \pm 1.18^{\mathrm{a}} \\
38.27 \pm 0.98^{\mathrm{b}}\end{array}$ & $\begin{array}{l}0.03 \pm 0.00^{\mathrm{a}} \\
0.02 \pm 0.00^{\mathrm{a}}\end{array}$ & $\begin{array}{l}27.62 \pm 2.40^{\mathrm{a}} \\
14.60 \pm 0.06^{\mathrm{b}}\end{array}$ & $\begin{array}{l}2.15 \pm 0.19^{\mathrm{a}} \\
0.89 \pm 0.03^{\mathrm{b}}\end{array}$ & $\begin{array}{l}\text { Wild } \\
\text { Cultured }\end{array}$ \\
\hline 17 & $\begin{array}{l}15.10 \pm 1.05^{\mathrm{a}} \\
14.93 \pm 0.91^{\mathrm{a}}\end{array}$ & $\begin{array}{l}3.94 \pm 0.18^{\mathrm{a}} \\
6.59 \pm 0.07^{\mathrm{b}}\end{array}$ & $\begin{array}{l}0.35 \pm 0.06^{\mathrm{a}} \\
0.00 \pm 0.00^{\mathrm{b}}\end{array}$ & $\begin{array}{l}2.41 \pm 0.17^{\mathrm{a}} \\
3.10 \pm 0.03^{\mathrm{b}}\end{array}$ & $\begin{array}{l}0.19 \pm 0.02^{\mathrm{a}} \\
0.51 \pm 0.02^{\mathrm{b}}\end{array}$ & $\begin{array}{l}0.75 \pm 0.06^{\mathrm{a}} \\
0.52 \pm 0.05^{\mathrm{a}}\end{array}$ & $\begin{array}{l}2.36 \pm 0.43^{\mathrm{a}} \\
2.64 \pm 0.14^{\mathrm{a}}\end{array}$ & $\begin{array}{l}0.00 \pm 0.00^{\mathrm{a}} \\
0.00 \pm 0.00^{\mathrm{a}}\end{array}$ & $\begin{array}{l}18.81 \pm 1.03^{\mathrm{a}} \\
10.27 \pm 0.98^{\mathrm{b}}\end{array}$ & $\begin{array}{l}22.58 \pm 1.41^{\mathrm{a}} \\
41.32 \pm 3.55^{\mathrm{b}}\end{array}$ & $\begin{array}{l}0.03 \pm 0.00^{\mathrm{a}} \\
0.03 \pm 0.00^{\mathrm{a}}\end{array}$ & $\begin{array}{r}23.9 \pm 1.29^{\mathrm{a}} \\
23.66 \pm 1.91^{\mathrm{a}}\end{array}$ & $\begin{array}{l}0.02 \pm 0.00^{\mathrm{a}} \\
0.74 \pm 0.02^{\mathrm{b}}\end{array}$ & $\begin{array}{l}\text { Wild } \\
\text { Cultured }\end{array}$ \\
\hline 19 & $\begin{array}{l}6.64 \pm 0.57^{\mathrm{a}} \\
5.99 \pm 0.32^{\mathrm{a}}\end{array}$ & $\begin{array}{l}3.37 \pm 0.12^{\mathrm{a}} \\
1.97 \pm 0.07^{\mathrm{b}}\end{array}$ & $\begin{array}{l}7.13 \pm 0.59^{\mathrm{a}} \\
0.00 \pm 0.00^{\mathrm{b}}\end{array}$ & $\begin{array}{l}3.26 \pm 0.63^{\mathrm{a}} \\
1.64 \pm 0.03^{\mathrm{b}}\end{array}$ & $\begin{array}{l}6.64 \pm 0.57^{\mathrm{a}} \\
0.32 \pm 0.06^{\mathrm{b}}\end{array}$ & $\begin{array}{l}0.49 \pm 0.00^{\mathrm{a}} \\
0.39 \pm 0.03^{\mathrm{a}}\end{array}$ & $\begin{array}{l}2.03 \pm 0.04^{\mathrm{a}} \\
1.83 \pm 0.02^{\mathrm{b}}\end{array}$ & $\begin{array}{l}0.00 \pm 0.00^{\mathrm{a}} \\
0.00 \pm 0.00^{\mathrm{a}}\end{array}$ & $\begin{array}{l}8.12 \pm 0.01^{\mathrm{a}} \\
4.44 \pm 0.24^{\mathrm{a}}\end{array}$ & $\begin{array}{l}24.47 \pm 1.06^{\mathrm{a}} \\
34.49 \pm 2.46^{\mathrm{b}}\end{array}$ & $\begin{array}{l}0.02 \pm 0.00^{\mathrm{a}} \\
0.02 \pm 0.00^{\mathrm{a}}\end{array}$ & $\begin{array}{l}10.51 \pm 0.47^{\mathrm{a}} \\
20.20 \pm 0.69^{\mathrm{b}}\end{array}$ & $\begin{array}{l}0.22 \pm 0.01^{\mathrm{a}} \\
1.29 \pm 0.02^{\mathrm{b}}\end{array}$ & $\begin{array}{l}\text { Wild } \\
\text { Cultured }\end{array}$ \\
\hline
\end{tabular}

AMN, amonia; PUT, putresine; KAD, kadaverine; HIS, histamine; SPD, spermidine; TRP, triptamin; PHEN, 2-phenylethylamine; SPN, spermin; SER, serotonin; TYR, tiramin; TMA, trimetilamin; AGM, agmatine. Different letters $(\mathrm{a}-\mathrm{b})$ in the same row show significant differences $(P<0.05)$. 


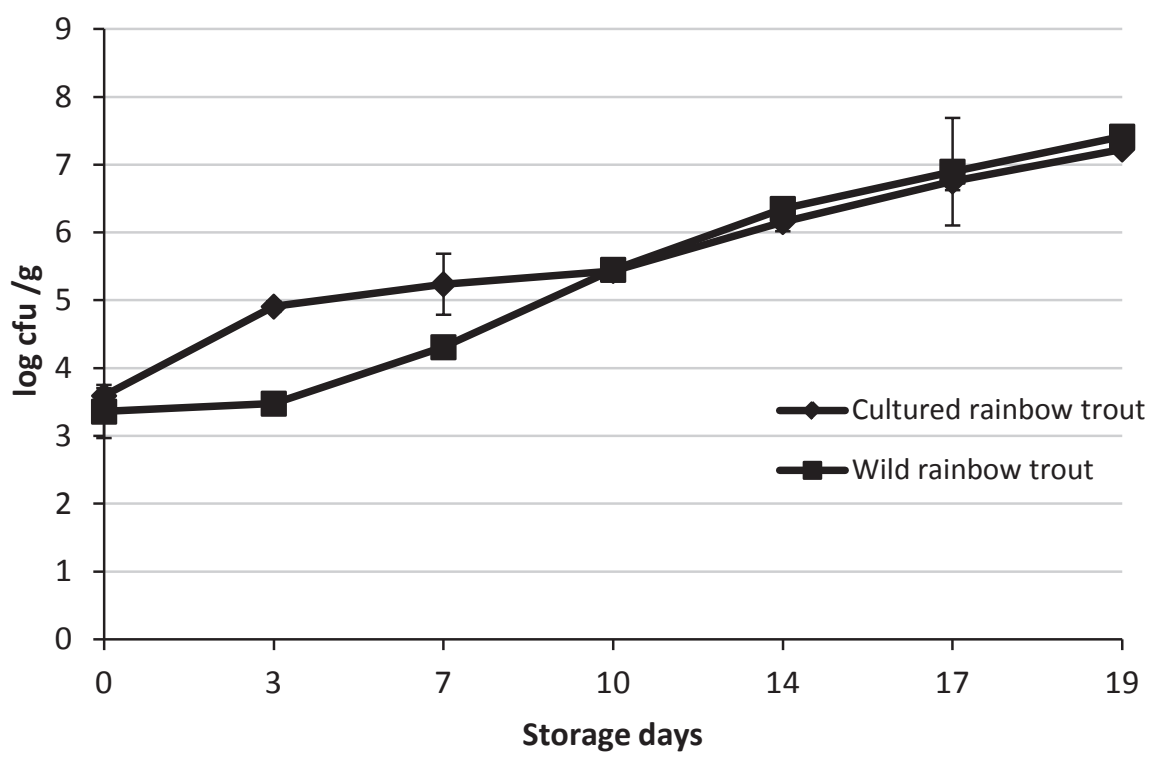

Fig. 3. TVC content of wild and cultured rainbow trout during storage time (days).

of putrescine ranged from 0.4 initially to $8.97 \mu \mathrm{g} / \mathrm{g}$, and psychrotrophic microorganisms were dominant. Histamine was detected only at later stages of storage.

Fish (mainly marine fish) contain trimethylamine oxide (TMAO) and the quantity depends on fish species, the environment, season, and size. Trimethylamine oxide (TMAO) is reduced to trimethylamine (TMA) by spoilage bacteria and TMA is associated with ammonia-like off-odour and 'fishy' off-flavours (Gram and Huss, 1996; Ólafsdóttir et al., 1997). In this study, the initial TMA value was $0.52 \mathrm{mg} / 100 \mathrm{~g}$ for wild rainbow trout and $0.04 \mathrm{mg} / 100 \mathrm{~g}$ for cultured rainbow trout. During storage, its level remained low in both groups (< $0.05 \mathrm{mg} / 100 \mathrm{~g}$ ) due to the being freshwater species.

Microbiological analyses Microbial counts on the wild and cultured rainbow trout are presented in Figure 3. Initial TVC of fish was $3.59 \log \mathrm{CFU} / \mathrm{g}$ for cultured rainbow trout and $3.36 \log \mathrm{CFU} / \mathrm{g}$ for wild rainbow trout, which showed high quality of fish. The microbiological limit recommended by the ICMSF (1986) for TVC at $30^{\circ} \mathrm{C}$ is $7 \log \mathrm{g}^{-1}$ or $\log$ $\mathrm{cm}^{-2}$ for fresh water and marine species. TVC increased with an increase in storage time, especially in the case of cultured rainbow trout until 10 days of storage. After that, wild rainbow trout contained higher TVC level than cultured rainbow trout. When fish were unacceptable at the days of 14, TVC content was $6.16 \log \mathrm{CFU} / \mathrm{g}$ for wild rainbow trout and 6.35 $\log \mathrm{CFU} / \mathrm{g}$ for cultured rainbow trout, indicating that sensory analyses correlated well with microbiological analyses. Rezaei and Hosseini (2008) reported that initial TVC content of rainbow trout was $4 \log \mathrm{CFU} / \mathrm{g}$ and increased to $7.04 \log$ $\mathrm{CFU} / \mathrm{g}$ after 20 days of ice storage. Similar results were reported for iced rainbow trout (Rezaei et al., 2007) and for vacuum packed rainbow trout (Nerantzaki et al., 2005).
In the present study, coliform and E. coli were not detected for both wild and cultured rainbow trout during storage period of 19 days, which showed no fecal contamination of fish from environment or during handling and catching.

\section{Conclusion}

The present study indicated that wild rainbow trout differed from cultured fish of the same species in terms of nutritional content. Wild fish have much higher fat contents and n-3 fatty acids than their cultured counterparts. This could result from the feed. Total lipid content, and fatty acid profile of fish depend upon the diet consumed. Sensory analyses showed that wild fish were preferred to cultured fish due to the taste and flavour. Chemical analyses showed that lipid oxidation and hydrolysis developed at a higher rate in wild rainbow trout. Although wild rainbow trout contained higher TVC level than cultured rainbow trout at the earlier stages of storage period, both groups gave similar TVC values for the rest of storage period,which indicated that sensory analyses correlated well with microbiological analyses.

\section{References}

AOAC. (1990). Official Methods of Analysis of the Association of the Official Analysis Chemists. Association of Official Analytical Chemists, $15^{\text {th }}$ edition. Washington, DC.

AOAC. 1998a. Official method 955.04. Nitrogen (total) in seafood. Fish and other marine products. In: Hungerford JM, chapter editor; Cunniff P, editor. Official methods of analysis of AOAC International. chapter 35, Arlington, VA, p. 6.

AOAC. 1998b. Official method 938.08. Ash of seafood. Fish and other marine products In: Hungerford JM, chapter editor; Cunniff $\mathrm{P}$, editor. Official methods of analysis of AOAC International. 
chapter 35, Gaithersburg, Maryland, p. 6.

AOAS. (1994). Official Methods and Recommended Practices of the American Oil Chemists' Society, the American Oil Chemists' Society, Champaign, IL.

Ackman, R.G. (1989). Seafood lipids and fatty acids. Food Rev. Int., 6, 617-646.

Al Bulushia, I., Pooleb, S., Deetha, H. C. and Dykes, G.A. (2009). Biogenic amines in fish: Roles in intoxication, spoilage, and nitrosamine formation. Crit. Rev. Food Sci. Nutr., 49, 369-377.

Aubourg, S.P. (1993). Review: interaction of malondialdehyde with biological molecules-new trends about reactivity and significance. Int. J. Food Sci. Tech., 28, 323-335.

Alasalvar, C., Taylor, K.D.A., Zubcov, E., Shahidi, F. and Alexis M. (2002). Differentiation of cultured and wild sea bass (Dicentrarchus labrax): total lipid content, fatty acid and trace mineral composition. Food Chem., 79, 145-150.

Antonocopoulus, N. (1973). Bestmmung des Flüchhtigen Basensticktoofs., 224-225. In: Ludorf, W., Meyer, V.; Fische und Fischerzeugnisse, Aulage Verlag Paul Parey, Berlin und Hamburg.

Blanchet, C., Lucas, M., Julien, P., Morin, R., Gingras, S. and Dewailly, E. (2005). Fatty acid composition of wild and farmed Atlantic salmon (Salmo salar) and rainbow trout (Oncorhynchus mykiss). Lipids, 40, 529-531.

Bligh, E.C. and Dyer, W.J. (1959). A rapid method of total lipid extraction and purification. Can. J. Biochem. Physiol., 37, 913-917.

Bodmer, S., Imark, C. and Kneubühl, M. (1999). Biogenic amines in food. Histamine and food processing. Inflammation Res., 48, 296-300.

Branch, A.C. and Vail, A.M.A. (1985). Bringing fish inspection into the computer age. Food Technol. Aust., 37, 352-355.

Cinquinaa, A.L., Calìa, A., Longoa, F., De Santisa, L., Severonib, A. and Abballeb, F. (2004). Determination of biogenicamines in fish tissues by ion-exchange chromatography with conductivity detection. J. Chromatogr. A, 1032, 73-77.

Chytiri S., Paleologos E., Savvaidis I. and Kontominas M.G. (2004). Relation of Biogenic Amines with Microbial and Sensory Changes of Whole and Filleted Freshwater Rainbow Trout (Onchorynchus mykiss) Stored on Ice. J. Food Prot., 67, 960-965.

Connel, J. J. (1995). Control of Fish Quality, 4th Edition. Fishing News Books Limited, London.

Dawood, A.A.; Roy, R.N. and Williams, C.S. (1986). Effect of delayed icing on the storage of life of rainbow trout. J. Food Technol., 21, 159-166.

EC Directive 95/149/EC: Commision decision of 8 March, 1995 fixing the total volatile base nitrigen (TVB-N) limit values for certain categories of fishery products and specifying the analysis methods to be used. Official Journal L 097, 29/04/1995. 00840087.

Fallah, A.A., Saei-Dehkordi, S.S. and Nematollahi,A. (2011). Comparative assessment of proximate composition, physicochemi- cal parameters, fatty acid profile and mineral content in farmed and wild rainbow trout (Oncorhynchus mykiss). Int. J. Food Sci. Technol., 46, 767-773

FDA (1996). Decomposition and histamine in raw, frozen tuna and mahi-mahi, canned tuna and related species. Compliance Policy Guides 7108.240, sec. 540.525.

Fernandez-Salguero, J. and Mackie, I.M. (1979). Histidine metabolism in mackerel (Scomber scombrus). Studies on histidine decarboxylase activity and histamine formation during storage of flesh and liver under sterile and non-sterile conditions. J. Food Technol., 14, 131-139.

Gram L. and Huss H.H. (1996). Microbiological spoilage of fish and fish products. Int. J. Food Microbiol., 33, 121-137.

Gimenez, B., Roncales, P. and Beltran, J.A., (2002). Modified atmosphere packaging of filleted rainbow trout. J. Sci. Food Agr., 84, 1154-1159.

Grigorakis, K., Alexis, M.N., Taylor, K.D.A. and Hole, M. (2002). Comparison of wild and cultured gilthead sea bream (Sparus aurata); composition, appearance and seasonal variations. Int. J. Food Sci. Technol., 37, 477-484.

Grigorakis K., Taylor K.D.A. and Alexis M.N. (2003). Organoleptic and volatile aroma compounds comparison of wild and cultured gilthead sea bream: sensory differences and possible chemical basis. Aquaculture, 225, 109-119.

Haliloğlu H. I., Aras N.M. and Yetim H. (2001). Comparison of Muscle Fatty Acids of Three Trout Species (Salvelinus alpinus, Salmo trutta fario, Oncorhynchus mykiss) Raised under the Same Conditions. Turk. J. Vet. Anim. Sci., 26, 1097-1102.

Howgate, P.F. (1982). Quality assessment and quality control, in Fish Handling and Processing ( $2^{\text {nd }}$ edition), (edited by Aitken A, Mackie IM, Merritt JH and Windsor ML), Her Majesty's Stationery, Edinburgh, pp. 177-186.

Huss, H.H., (1988). Fresh Fish: Quality and quality changes. Rome: Food and Agriculture Organization (FAO) of the United Nations. pp.132.

Ichihara, K., Shibahara, A., Yamamoto, K. and Nakayama, T., (1996). An improved method for rapid analysis of the fatty acids of glycerolipids. Lipids, 31, 535-539.

International Commission on the Microbiological Specifications for Foods (ICMSF) 1986. Microorganisms in Foods 2. Sampling for Microbiological Analysis: Principles and Specific Applications, 2nd ed. Blackwell Scientific Publications, London.

Krizek, M., Vacha, F., Vorlova, L., Lukasova, J. and Cupakova, S. (2004). Biogenic amines in vacuum-packed and non-vacuum packed flesh of carp (Cyprinus carpio) stored at different temperatures. Food Chem., 88, 185-191.

Kyrana, V.R., Lougovois, V.P. and Valsamis, D.S. (1997). Assessment of shelf-life of maricultured githead seabream (Sparus aurata) stored in ice. Int. J. Food Sci. Technol., 32, 339-347.

Mackie, I.M., Pirie, L., Ritchie, A.H. and Yamanaka, H. (1997). The 
formation of non-volatile amines in relation to concentrations of free basic amino acids during postmortem storage of the muscle of scallop (Pecten maximus), herring (Clupea harengus) and mackerel (Scomber scombrus). Food Chem., 60, 291-295.

Nasopoulou, C., Zabetakis, I. (2012). Benefits of fish oil replacement by plant originated oils in compounded fish feeds. $L W T$ Food Sci. Technol., 47(2), 217-224.

Nerantzaki, A., Tsiotsias, A., Paleologos, E.K., Savvaidis, I.N., Bezirtzoglou, E. and Kontominas, M.G. (2005). Effects of ozonation on microbiological, chemical and sensory attributes of vacuum packaged rainbow trout stored at $4^{\circ} \mathrm{C}$. Eur. Food Res. Technol., 221, 675-683.

Nishimoto, J. Suwetja, I.K. and Miki, H. (1985). Estimation of keeping freshness period and practical storage life of mackerel muscle during storage at low temperatures. Memoirs of the Faculty of Fisheries. Kagoshima University, 34, 89-96.

Olafsdottir, G., Martinsdóttir, E., Oehlenschlager, J., Dalgaard, P., Jensen, B., Undeland, I., Mackie, I.M., Henehan G., Nielsen, J. and Nilsen, H. (1997). Methods to evaluate fish freshness in research and industry. Trends Food Sci. Tech., 8, 258-266.

Ozogul, F. and Ozogul, Y. (2000). Comparison of methods used for determination of total volatile basic nitrogen (TVB-N) in rainbow trout (Oncorhynchus mykiss), Turk. J. Zool., 24, 113-120.

Ozogul, F, Taylor, K.D.A., Quantick, P. and Ozogul, Y. (2002). Biogenic amines formation in Atlantic herring (Clupea harengus) stored under modified atmosphere packaging using a rapid HPLC method. Int. J.Food Sci. and Technol., 37, 515-522.

Ozogul, Y. and Ozogul, F., (2004). Effects of slaughtering methods on sensory, chemical and microbiological quality of rainbow trout (Onchorynchus mykiss) stored in ice and MAP. Eur. Food Res. Technol., 219, 211-216

Ozogul, Y., Ahmad, J.I., Hole, M., Ozogul, F. and Deguara, S. (2006). The effects of partial replacement of fish meal by vegetable protein sources in the diet rainbow trout (Onchorynchus mykiss) on post mortem spoilage of fillets. Food Chem., 96, 549561.
Ozogul, Y., Ozogul, F. and Alagöz, S. (2007). Fatty acid profiles and fat contents of commercially important seawater and freshwater fish species of Turkey. Food Chem., 103, 217-223.

Redmond, J.W. and Tseng, A. (1979). High-pressure liquid chromatographic determination of putrescine, cadaverine, spermidine and spermine. J. Chromatogr., 170, 479-481.

Rezaei, M., Montazeri, N., Langrudi, H.E., Mokhayer, B., Parviz, M. and Nazarinia, A. (2007).The biogenicamines and bacterial changes of farmed rainbowtrout (Oncorhynchus mykiss) stored in ice. Food Chem.,103, 1150-154.

Rezaei, M. and Hosseini, S.F. (2008). Quality Assesment of Farmed Rainbow Trout (Onchorynchus Mykiss) during chilled storage. J. Food Sci., 73, 93-96.

Rodriguez, C.J., Besteiro, I. and Pascual, C. (1999). Biochemical changes in freshwater rainbow trout (Oncorhynchus mykiss) during chilled storage. J. Sci. Food Agr., 79, 1473-1480.

Shahidi, F. and Botta, J.R. (1994). Seafoods: Chemistry, processing technology and quality (pp. 3-9). London: Chapman \& Hall.

Tarladgis, B., Watts, B.M. and Yonathan, M. (1960). Distillation method for determination of malonaldehyde in rancid food. $J$. Am. Oil Chem. Soc., 37, 44-48.

Tejada, M. and Huidobro, A. (2002). Quality of farmed gilthead seabream (Sparus aurata) during ice storage related to the slaughter method and gutting. Eur. Food Res. Tech., 215, 1-7.

Tokur, B., Çaklı, Ş. and Polat, A., (2006). The quality changes of trout (Oncorhynchus mykiss W., 1792) with a vegetable topping during frozen storage $\left(-18^{\circ} \mathrm{C}\right)$. J. Fish. Aquat. Sci., 23, 345-350.

Wunnenberg, J. and Oehlenschläger, A. (2008) Investigations on shelf life of ice-stored aquacultured rainbow trout (Oncorhynchus mykiss) in relation to annual seasonal factors by application of the Quality Index Method (QIM) for gutted whole fish and sensory assessment for cooked fillets. Archiv. Lebensm., 59, 221-226.

Vliet, T. van and Katan M.B. (1990). Lower ratio of n-3 to n-6 fatty acids in cultured than in wild fish. Am. J. Clin. Nutr., 51, 1-2.

Zhou, X., Ding Y. and Wang, Y. (2012). Proteomics: present and future in fish. shellfish and seafood. Rev. Aquaculture, 4, 11-20. 